the Babylonian Chronicle, but also on account of his name and its varying forms. ? Perhaps, however, he regarded himself as an Assyrian ( $\Rightarrow$ Babylonian) because he was a vassal of Nabonidus, in which case the expression would simply mean that he was a Babylonian subject.

I Gubaru, Gubarm, and Ligharu, which, it might be argued, show that the pronunciation was G'birz. The Greek Gobryas, on the other hand, implies a form lilie Gubru.
But the important point in this second inscription is the statement that Gubarru (Gobryas) was governor of Babylon, and that he was the person sinned against if Ardia failed to deliver the 5 talents of dates required for the royal palace at Erech. As the official replacing the king, he evidently had royal power, and this tablet, like that mentioning Belshazzar, adds one more to the arguments that the Book of Daniel may not be so incorrect, historically, as it is commonly held to be.

\title{
Mational Thate.
}

\section{By the Rev. John Pinkerton, B.D., Edingurgh.}

\footnotetext{
"Fur the day of the Lord is near upon all the heathen : as thou hast done, it shall be done unto thee: thy reward shall return upon thine own head.

'And saviours shall come up on mount Kion to judge the mount of Esau; and the kineslom shall be the Iord ss.Ob 15,21 .

'Love your enemies.'-Nit $5^{44}$.
}

$W_{E}$ have heard much recently of a Hymn of Hate. That production has been received by some as if nothing similar to it had ever been made before. However true that impression may be in ont respect, in another it is not well founded. This is not the first century in which nations have regarded each other with hatred. Two thousand live hundred years ago there were two peoples who hated each other with an extreme and lasting hate, and some writings, in which that hate was expressed, have found a place in the world's literature. These two peoples were the Hebrews and the Edomites. Their lands bordered each other in southern Palestine, and between them an intermittent warfare was waged for centuries. The hatred of the Hebrews against the Edomites found expression in many a hy'mn and prophecy, some of which are now preserved in the Hebrew Scriptures, e.g. the prophecy of Obadiah. There were doubtless many such of Edomite origin, but Time has robbed us of them all.

The hatred between these two peoples was remarkable in view of their many common interests. Racially they were closely related to each other. Obadiah and others speak of the relationship as that of brothers. 'Look not thou on the day of thy brother,' says Obadiah: and Amos accuses
Edom of having pursued his brother with the sword. This intimate connexion is also witnessed to by the story that Jacob and Esau, the ancestors from whom these two peoples were descended, were twins. The languages they spoke belonged to the same stock, and, so far as we know, differed little from each other. Recent investigation has shown that certain of their religious practices were identical. Their position as buffer-states between two great empires-Egypt on the west, and Assyria or Babylonia on the east-strongly suggested that instead of wasting their powers in mutual strife they should unite their forces for mutual protection. But no! their animosity only increased with the passing centuries, so much so that the harm of the one was the joy of the other. It was with tumultuous gladness, Obadiah tells us, that the Edomites greeted the conquest of Judiea by the Babylonians in 586 . To show how Israel reciprocated this hate, it need only be said that never do we find such hard things said about Babylon for all the sufferings it imposed on the Hebrews, as we find said about Edom.

What gave rise to this 'perpetual hatred,' as Ezekiel calis it, is unknown to us. It is certain that the Edomites were in many ways a favoured people. Their land though wild and mountainous contained many fertile valleys, and their position on one of the great trade-routes of the East-the route between Arabia and Asia Minor-enabled them to accumulate wealth as 'middlemen.' This may at times have excited the jealousy and cupidity of the Hebrews.

But the 'perpetual hatred' was probably due to 
a deeper cause. The Edomites, as a people, seem to have been concerned mainly about what they should eat, and what they should drink, and wherewithal should they be clothed. In the character of the patriarch Esau we have the typical Edomite -a man taking no thought of the future, making light of birthrights and inherited powers, when material pleasures were at stake. They had no use for a people like the Hebrews, who felt they had a destiny, and were endeavouring to have that destiny realized. Edom wanted to make Israel subservient to its plans for money-making. Israel resented the interference of Edom, and the feud thus begun deepened to a hatred almost unparalleled in the history of man. The wrong done by Edom to Israel was further aggravated by the fact that the people who might have been expected to give sympathy and support gave nothing but antipathy and contempt. Israel asked for bread, and received a stone.

History often repeats itself, and to-day the world again sees the spectacle of two kindred nations hating each other with a cordial hatred. Of the fact that at least a large part of the German people hates this nation, there is incontestable proof. As to ourselves there is much ground for believing that the exasperation felt by this people at the reckless way in which Germany plunged Europe into war is deepening into a more intense and fierce passion. Yet Britons and Germans are descended from a common Teutonic stock. The two languages are not widely different from each other. Commercially and industrially they have been closely connected. In view, therefore, of their many common interests, there is ground for wonder at the feelings of hate which exist between the two peoples. The situation which confronts us now bears so many resemblances to that which existed between Israel and Edom, that a consideration of their relationship cannot but be of advantage.

\section{The nation whose greatest inspiration is a} hatred, is doomed.

History has two outstanding facts to record about the Edomites: (I) they were great haters; (2) they have perished.

I think that we may with assurance believe these two facts to be related to each other somewhat as cause and effect.

Of the manifestations of the human spirit, hatred is one of the most evil. It is like a noxious weed of rank growth, which getting root in a good garden gradually overruns it and reduces it to waste. Hatred warps the judgment and spoils the nature. It narrows the outlook-any one who knows a man who has a great grudge knows that that man's outlook is narrow. So absorbed is he in one interest, and that an evil one, that he ceases to develop his other spiritual capacities, and loses the power of appreciating other and higher interests. Hatred can thus result in the destruction of all the finer qualities of the spiritual nature of men. Just as an offence against the laws that govern the physical universe, e.g. the law of gravitation, means the injury of the offender, so an offence against those laws which control the spiritual universe involves the offender in spiritual injury. Hatred by reason of the way in which it makes the spiritual nature weak and imperfect constitutes an offence against the spiritual wellbeing of mankind, and with inevitable force the laws governing the spiritual universe work the destruction of the offender.

Edom hated Israel with a bitter hatred, but the main result of that hatred was the destruction of Edom. Edom had no love for the high things of which Israel at its best was in search, and it gradually lost the power of appreciating these things. The only inspiring motive which Edom had was hatred of all who sought high inspiration. The end was sure: no nation can live by hate, for hate blights. "Where there is no vision, the people perish.' There was no vision in Edom, and Edom perished-a warning to all that the nation whose one inspiration is a great hatred, is doomed.

This hatred on the part of those whose tastes are material and earthy against those who can and do appreciate what is true and noble and spiritual, has been manifested by many races and classes other than the Edomites. Perhaps it has had no clearer illustration than the hatred felt by the world to Christ and His followers.

In St. John's Gospel this hatred is compared to the opposition between light and darkness. Christ says: 'And this is the condemnation that light is come into the world, and men loved darkness rather than light, because their deeds were evil. For every one that doeth evil hateth the light.' Again He says: 'The world hath hated me.' But such hatred is futile-it works its own 
destruction. While Israel has lived, Edom has perished. The darkness of the pagan world is steadily vanishing before the light of the gospel. And it will be the same always. Even to-day as we know it to be in Germany, where a people is living in hatred of those who esteem what mankind acknowledges to be the highest and the best, there, we may be assured, the principle is operating, and such a people is working its own hurt.

Such a reading of the past is eloquent in its warning to us that by allowing our present feelings of resentment to deepen into hate, we would only be doing ourselves a great wrong.

II. The saving power of a nation at a time zehen the hatred of other peoples is set against it, is a firm belief in the justice of the government of the universe.

In many respects Edom was stronger than Israel. The land was practically impregnable, and the people possessed material resources which Israel never enjoyed. Yet it was Israel which prevailed in the long-drawn conflict. Against great odds it sustained itself by an indomitable belief that justice would be done to it, and that the cause which it championed would yet be acknowledged as right. This belief was expressed in passionate appeals to God to manifest $\mathrm{H}$ is power in deliverance and to hasten the day of the Lord, or in a confident expectation that soon the might of God would prevail. Obadiah expresses this hope thus: "And saviours shall come up on mount Zion to judge the mount of Esau; and the kingdom shall be the Lord's.'

There is much in human experience which seems to give the lie to the belief that there is an order in the universe, and that it is a just order. But deep down in the human breast there is the belief that, even because we have the knowledge of justice, there must be justice somewhere in this universe. Faith in justice and in the rationality of existence was strong in the Hebrew mind, and sustained it in spite of much trial. And a like faith has been found in every people or class or age which has been firmly persuaded of the truth which it professes, whatever that tiuth be. The early Christians were firmly convinced that the way of life in Jesus Christ was the highest life for man, and in the face of much persecution they held to that conviction. They believed that the world was founded on justice, and that all that was in accordance with the righteousness of God, revealed in Christ, must prevail because of this justice. Without this faith they would have failed. And their faith is being more fully justified each succeeding century.

But this belief in the Divine justice must be large enough to allow for a disciplining of one's own people or class. The people that thinks that God's judgments ought to fall only on other peoples, is probably just the very people by whom they are most required. The spiritual greatness of the Hebrew prophets is visible in nothing so much as in their recognition that the judicial processes of the Almighty would act adversely on their own people. They realized that there is no respect of persons with God, and that no people-no, not even Israel-had entirely succeeded in becoming 'the kingdom of God on earth.' The justice of God which saved Israel from Edom's hate also disciplined Israel.

We are at the present time oppressed with the hate of a great foe. His determination and resources might well induce feelings of disquiet. But strength and comfort can most surely be found in a steadfast faith in the justice of the world's government. We feel ourselves to be the custodians of certain ideals - ideals of honour, purity, and brotherhood, ideals of which our foe thinks lightly, and hates us for thinking highly. But as there is justice at the basis of the world's government, it must be that these ideals will prevail, that we shall be saved, and that the enemy's hate will result only in his shame.

Let us, however, also frankly recognize that that same justice may have to deal with us in discipline. Let us remember that we are fighting not only or mainly for the integrity of the British Empirewe are fighting for furity and honour. But before purity and honour can be established on the earth, the just God above who rules the destiny both of Britain and of Germany will have to discipline this people, so that all that is impure and dishonourable may be banished from our midst. As long as the 'white slave' haunts our streets, or the fraudulent financier our markets, our claim to be the defenders of purity and honour is in some measure weakened. We can be sure that the justice of God, which can and will protect us from the hate of a vengeful foe, will also chastise us for the sin that is in us. 
III. The justice of God is vindicated, not in the destruction, but in the salvation or perfecting of all soho hate.

The leaders of Hebrew thought believed that God would vindicate His justice in the extermination of those who hated His servants. Accordingly their almost constant prophecy was that the day of the Lord, the day of doom and death, was coming upon their foes. In entertaining such ideals they revealed one of the limitations under which they lived. 'Love thy neighbour, and hate thy enemy,' was the law they followed. They lived under a dispensation which had not outgrown the old law of retribution-'An eye for an eye, and a tooth for a tooth.'

But since their time a new dispensation, associated with the life and work of Jesus, has been inaugurated, and its law is 'Love your enemies.' Jesus asserts that, not by hating one's enemy, but by loving one's enemy, is the justice of God to be vindicated. Reflexion shows that this wonderful command is right, this amazing statement true. What do we mean by the justice of God? God's justice is His sense of what is right and true and perfect, and His desire that all things shall be right and true and perfect in the world $\mathrm{He}$ has made. Now the man (or the nation) devoted to hate is, we have seen, imperfect, but his imperfection is not going to be remedied by his destruction, any more than an imperfection in his eye-sight is to be remedied by taking out his eye. The imperfection of his hate will be remedied only by the development of those capacities which are temporarily overcome by his hate. God does not execute His justice by destroying men, but by changing and transforming men. And to change a man or a world there is no power equal to the power of love-that love which is sometimes disciplinary, is always wise, and is never destructive.

Under this new dispensation we live. We are baptized in the name of $\mathrm{Him}$ who inaugurated it, and at His table we have pledged ourselves to $\mathrm{His}$ cause. If we would be worthy followers, we shall never go back to that Old Testament time and pray for a Day of the Lord to destroy them who hate us, but in all our dealings with our enemy, yea, in our fighting with him, we shall act in love, and not in hate. We shall strive earnestly for the victory, because our victory will be for the disciplining of our foe, but we shall always entertain towards him larger and nobler feelings than he now entertains towards us. We shall look forward to the time when the exercise of the more kindly offices of love shall be possible, and when by these that which is now imperfect shall be supplied and made perfect, when justice-God's justice, not man's justice-shall prevail on the earth, and 'the kingdom shall be the Lord's.'

\section{Eiterature.}

\section{$Z E U S$}

THE most important contribution to the comparative study of Religion since the completion of Dr. Farnell's Cults of the Greek States has been made by Mr. A. B. Cook, Reader in Classical Archeology to the University of Cambridge. It is the first of two volumes entitled Zeus: A Study in Ancient Religion (Cambridge: At the University Press; 45s. net).

'It would seem that the Greeks, starting from a sense of frank childish wonder, not unmixed with fear, at the sight of the animate sky, mounted by slow degrees of enlightenment to a recognition of the physical, intellectual, and moral supremacy of the sky-god. Dion Chrysostomos in a memorable sentence declared Zeus to be " the giver of all good things, the Father, the Saviour, the Keeper of mankind." On the lower levels and slopes of this splendid spiritual ascent the Greeks found themselves at one with the beliefs of many surrounding peoples, so that a fusion of the Hellenic Zeus with this or that barbaric counterpart often came about. On the higher ground of philosophy and poetry they joined hands with a later age and pressed on towards our own conceptions of Deity. I have therefore felt bound to take into account not only the numerous adaptations of Levantine syncretism but also sundry points of contact between Hellenism and Christianity.'

In these words $\mathrm{Mr}$. Cook shows at once how vast is the subject he has undertaken to study, and 